\title{
Changing direction and magnitude of india's coffee export in the post-liberalization era
}

\begin{abstract}
An attempt has been made in this paper to study the direction of trade, trade competitiveness and stability in the export and changes in the export of Indian coffee. The study revealed that barring the year 1997, coffee is perfectly competitive with its NPC value being less than unity till 2000 and from 2000 onwards, the domestic price for coffee in India is more competitive than the international prices. The results of Markov Chain analysis revealed that other countries are the most stable importer of the Indian coffee while Spain is the least stable importer compared to other countries.
\end{abstract}

Keywords: coffee, compound growth rate, NPC, markov chain analysis
Volume 2 Issue I - 2018

\author{
Vinod Naik R, Nethrayini KR \\ Department of Agricultural Economics, University of \\ Agricultural Sciences, India
}

\begin{abstract}
Correspondence: Vinod Naik R, Department of Agricultura Economics, University of Agricultural Sciences, Dharwad-580 005, India, Email naikvinod00@gmail.com
\end{abstract}

Received: July 22, 2017 | Published: January 17, 2018
Abbreviations: ICA, international coffee agreement; ICO, international coffee organization; FAO, food and agricultural organization; CGR, compound growth rate; NPC, nominal protection coefficient; MAD, minimum absolute deviations; $\mathrm{CCD}$, café coffee day

\section{Introduction}

Coffee is of global importance, ranking second to petroleum in the world commodity trade. Moreover, coffee is of particular importance as a major export commodity in many low-income and developing countries in Latin America, Africa and Asia. Coffee was one of the first commodity in which control over world trade was attempted. Brazil, producing from 75 to 90 percent of the world's coffee in the early 1900 's, led Columbia and other Latin American countries to a series of producer-country agreements to control exports and raise world prices from 1902 until the first International Coffee Agreement was signed in 1962. This agreement represented a major change in the world coffee market since major coffee importing countries (including the USA) also became signatories. The International Coffee Agreement (ICA) is an international commodity agreement aimed to achieve a reasonable balance between the supply and demand of coffee. Export quotas are the principal instruments used. The original agreement was signed in 1962 for a five-year period, and since then there have been five subsequent agreements, ratified in 1968, 1976, 1983, 1994, and 2001. International Coffee Organization (ICO) exporting members account for over 97 percent of world coffee production and its importing members are responsible for around 80 percent of world coffee consumption. The coffee industry currently has a commodity chain that involves producers, middlemen exporters, importers, roasters, and retailers before reaching the consumer. Middlemen exporters often referred to as coffee "coyotes," purchase coffee directly from small farmers. Large coffee estates and plantations often export their own harvests or have direct arrangements with a transnational coffee processing or distributing company. India is the sixth largest producer of coffee in the world, accounting for over four percent of world coffee production, with the bulk of all production taking place in its Southern states. It is believed that coffee has been cultivated in India longer than anywhere outside of the Arabian Peninsula. Indian coffee is said to be the finest coffee grown in the shade rather than direct sunlight anywhere in the world. There are approximately 250,000 coffee growers in India, 98 percent of them are small growers. Almost 80 percent of the country's coffee production is exported. Of that which is exported, 70 percent is bound for Germany, Russian federation, Spain, Belgium, Slovenia, United States, Japan, Greece, Netherlands and France. In the backdrop of these issues, the present study is an attempt to evaluate the growth and instability in the export of coffee, its trade competitiveness in the world market and direction of trade and changing pattern of exports of coffee.

\section{Methodology}

Till 1995, the Coffee Board had a pool (controlled) marketing system of coffee in India. However, the winds of liberalization swept the Indian coffee industry and since 1995, marketing of coffee is strictly a private sector activity. Therefore, the period from 1995-96 to 2009-10 was purposively considered for the study. Data for the study were collected from various sources. Time series secondary data on the export quantity, destination wise of exports, wholesale prices of coffee in various major consuming centers in India have been compiled from Indiastat and other various sources like Food and Agricultural Organization (FAO), published journals, periodicals and websites for a period of 1995-96 to 2009-10 (Post liberalization of coffee industry) for coffee. The information on international prices (composite indicator prices) of coffee was compiled from International coffee organizations. The analytical tools employed in the present study are elaborated as under.

\section{Compound growth rate model}

The growth in quantity of export of coffee was analyzed using the compound growth rate (CGR). CGR was computed using log-linear model.

$\ln \mathrm{yt}=\alpha_{\mathrm{t}}+\beta_{\mathrm{t}}+\mathrm{u}_{\mathrm{t}}$

Where,

$\mathrm{y}_{\mathrm{t}}=$ Quantity (tons) of coffee in year $\mathrm{t}$.

$\mathrm{t}=$ Time element which takes the value $1,2 \ldots \ldots \ldots \ldots . . \mathrm{n}$ for various years.

$\alpha_{t}=$ Intercept
$\beta_{t}=$ Regression coefficient

Annual compound growth rate $(r)=\left[\left(\right.\right.$ Antilog $\left.\left.\beta_{t}\right)\right] \times 100$ 


\section{Instability analysis}

The formula suggested by Cuddy and Della (1978) was used to compute the index of instability. Instability index was used to study the stability of exports over the years.

Standard Deviation $(\sigma)$

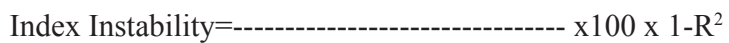

Mean (X)

\section{Export competitiveness (Nominal Protection Coefficient-NPC)}

Nominal Protection Coefficient (NPC) of Indian coffee was estimated for the period (1995-96 to 2010-11) in order to examine its export competitiveness in the World market. Nominal Protection Coefficient is a straight forward measure of competitiveness. It is calculated as a ratio between the domestic prices to the International price of a comparable grades of commodity, adjusted for all the transfer costs such as freight, insurance, handling costs, margins, losses etc. If NPC is less than one, the commodity is competitive (under importable hypothesis it is considered a good import substitute and under exportable hypothesis it is worth exporting). If NPC is greater than one, the commodity is not competitive (not a good import substitute or not worth exporting). NPC can be estimated under two main hypotheses i.e., under importable hypothesis and exportable hypothesis. Under importable hypothesis the commodity in question i.e., coffee is regarded as an import substitute and it is imported and it competes with domestically produced commodity in domestic market. The transfer cost i.e., the International and domestic transportation costs extend a sort of protection to the domestic commodity. Under exportable hypothesis, the commodity in question is treated as exportable commodity and thus competes with internationally produced commodity at a foreign port. Therefore, the domestic commodity has to be extra efficient to the tune of international transportation costs at least.

Symbolically,

$\mathrm{NPC}=\mathrm{P}_{\mathrm{d}} / \mathrm{P}_{\mathrm{b}}$

Where,

$P_{d}$ - Domestic whole sale price of coffee

$\mathrm{P}_{\mathrm{b}}$ - World reference price of coffee

\section{Markov Chain analysis}

Annual export data for the period 1995-96 to 2009-10 were used to analyze the direction of trade and changing pattern of exports of coffee. The major coffee importing countries namely Belgium, Germany, Italy, Russian Federation and Spain were considered while rest of the world considered as 'other' countries. The trade directions of commodities exports were analyzed using the first order Markov chain approach. Central to Markov chain analysis is the estimation of the transitional probability matrix $P$. The elements $P_{i j}$ of the matrix $P$ indicates the probability that export will switch from country $i$ to country $j$ with the passage of time. The diagonal elements of the matrix measure the probability that the export share of a country will be retained. Hence, an examination of the diagonal elements indicates the loyalty of an importing country to a particular country's exports. In the context of the current application, structural changes were treated as a random process with selected importing countries. The average exports to a particular country was considered to be a random variable which depends only on the past exports to that country, which can be denoted algebraically as

$\mathrm{r}$

$E_{j t}=\Sigma E_{i t}-1 * P_{i j}+e_{j t}$

$\mathrm{i}=1$

Where,

$E_{j t}=$ Exports from India to $j^{\text {th }}$ country during the year $t$.

$\mathrm{E}_{\mathrm{it}}-1=$ Exports to $\mathrm{i}^{\text {th }}$ country during the period $\mathrm{t}-1$.

$\mathrm{P}_{\mathrm{ij}}=$ Probability that the exports will shift from $\mathrm{i}^{\text {th }}$ country to $\mathrm{j}^{\text {th }}$ country.

$e_{j t}=$ The error term which is statistically independent of $E_{i t}-1$.

$\mathrm{t}=$ Number of years considered for the analysis

$\mathrm{r}=$ Number of importing countries

The transitional probabilities $\mathrm{P}_{\mathrm{ij}}$ which can be arranged in $\mathrm{a}\left(\mathrm{c}^{*} \mathrm{r}\right)$ matrix have the following properties.

$\mathrm{O} \leq P_{i j} \leq 1$

$\mathrm{n}$

$\Sigma P_{i j}=1$ for all $\mathrm{i}$

$\mathrm{i}=1$

Thus, the expected export shares of each country during period ' $t$ ' were obtained by multiplying the export to these countries in the previous period ( $\mathrm{t}-1)$ with the transitional probability matrix. To estimate the transitional probabilities of the Markov chain model Minimum Absolute Deviations (MAD) estimation procedure was employed, which minimizes the sum of absolute deviations. The conventional linear programming technique was used, as this satisfies the properties of transitional probabilities of non-negativity restrictions and row sum constraints in estimation.

The linear programming formulation is stated as

Min $\mathrm{OP}^{*}+\mathrm{Ie}$

Subject to,

$\mathrm{XP}^{*}+\mathrm{V}=\mathrm{Y}$

$\mathrm{z}$ GP*=1

$P^{*} \geq 0$

Where,

0 - is the vector of zeroes.

$\mathrm{P}^{*}$ - is the vector in which probability $\mathrm{P}_{\mathrm{ij}}$ are arranged.

I- is an apparently dimensioned vector of area.

E- is a vector of absolute error (1 U 1).

Y- is the vector of export to each country.

$\mathrm{X}$ - is the block diagonal matrix of lagged values of $\mathrm{Y}$

$\mathrm{V}$ - is the vector of errors

G- is the grouping matrix to add the row elements of $\mathrm{P}$ arranged in $\mathrm{P}^{*}$ to unity. 
Using the estimated transitional probabilities, the exports of coffee to various destinations were predicted by multiplying the same with the respective shares of base year. The values in the transitional probabilities matrix will have different interpretations. The value of diagonal elements indicates the probability of retention of the previous year values, while values in columns reveals probability of gain of a particular country from other countries, values in rows reveals probability that a country might lose to their countries in respect of a specific commodity exports.

\section{Results and discussion}

\section{Global and Indian scenario of coffee production and export}

Global and India's production and export scenario of coffee is presented in Table 1. It visualized from the table that, there has been an increase in the global coffee production since 1995-96. The quantity of coffee traded in the international market has also increased considerably over the study period. The closer examination of the figures indicates that India's contribution in the global coffee production has declined from 4.36 percent during 1995- to 3.90 percent in the year 2009-10. Similarly the share of India in the global coffee export also declined from 4.83 percent (1995-96) to 3.26 percent (2009-10). Perusal of the Figure 1 indicates that, actual quantity exported is more than the targeted export over the study period, thus making coffee as one of the prime commodities involved in foreign trade from India. Interestingly Table 1 also revealed that the percentage of coffee exported from India from the total coffee production has declined considerably from 94.10 percent to 64.39 percent over the study period. The reasons for decline in contribution is attributed to rise in consumption of coffee in India after 2000 and setting up of café coffee day (CCD), Barista, Java Green, Café Mocha and other retail outlets on commercial lines specially in metros and big cities. Rise in coffee culture and flocking of coffee parlors among metros and big cities in India have all contributed to increase in the consumption of coffee. The internal consumption of coffee in India rose to 80,000 tonnes in 2005 , a positive change since the years, not so very long ago, when consumption was static at 55,000 tonnes per annum. The growth of coffee consumption in recent years is estimated at a healthy 6 percent per annum, bringing India squarely onto the radar of global coffee companies as a consuming, and not just a producing and exporting country. Liberalization of the Indian coffee industry in the year 1996-97 has significantly altered the landscape for coffee growers and exporters, as well as retailers. Today, the coffee retail scene in India is thriving like never before. The burgeoning coffee bars in India have been identified as one of the more visible signs of a booming consumer economy.

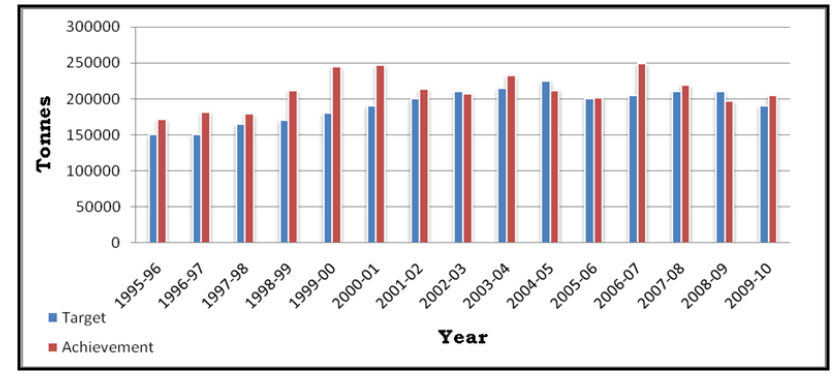

Figure I Target and achievement of coffee export from India.

Table I Production and export of coffee in world and India (ICO members) (In '000s bags of 60 kilo each)

\begin{tabular}{llllllll}
\hline \multirow{2}{*}{ Year } & \multicolumn{2}{l}{ Production } & India's share (\%) & \multicolumn{2}{l}{ Exports } & India's share (\%) & \% of india's export to production \\
\cline { 2 - 3 } \cline { 6 - 7 } & World & India & & World & India & \\
\hline $1995-96$ & 85250 & 3717 & 4.36 & 74014 & 3572 & 4.83 & 96.10 \\
$1996-97$ & 101865 & 3417 & 3.35 & 81745 & 2476 & 3.03 & 72.46 \\
$1997-98$ & 95872 & 3805 & 3.97 & 77806 & 3685 & 4.74 & 96.85 \\
$1998-99$ & 106163 & 4417 & 4.16 & 82554 & 3442 & 4.17 & 77.93 \\
$1999-00$ & 115117 & 4867 & 4.23 & 92282 & 4214 & 4.57 & 86.58 \\
$2000-01$ & 116619 & 5020 & 4.3 & 89248 & 4229 & 4.74 & 84.24 \\
$2001-02$ & 108451 & 5010 & 4.64 & 90564 & 3730 & 4.12 & 74.45 \\
$2002-03$ & 123723 & 4588 & 3.71 & 90007 & 3567 & 3.96 & 77.75 \\
$2003-04$ & 103982 & 4508 & 4.34 & 87527 & 3826 & 4.37 & 84.87 \\
$2004-05$ & 116062 & 4592 & 3.96 & 89546 & 2790 & 3.12 & 60.76 \\
$2005-06$ & 111463 & 4567 & 4.10 & 88222 & 3581 & 4.06 & 78.41 \\
$2006-07$ & 129138 & 4800 & 3.72 & 97620 & 3065 & 3.14 & 63.85 \\
$2007-08$ & 119396 & 4367 & 3.66 & 96078 & 3389 & 3.53 & 77.60 \\
$2008-09$ & 128181 & 4372 & 3.41 & 97584 & 3286 & 3.37 & 75.16 \\
$2009-10$ & 123713 & 4827 & 3.90 & 95466 & 3108 & 3.26 & 64.39 \\
\hline
\end{tabular}

\section{Source: FAOSTAT, 2010}

\section{Growth and instability in the export of Indian coffee}

The compound growth rates and instability index of Indian coffee export in quantity for the period 1995-96 to 2009-10 are presented in
Table 2. It could be seen from the table that over the year the quantity wise total export of Indian coffee exports grew marginally at the rate of 0.93 percent per annum and it was found non-significant. With 
respect to country-wise analysis, the growth in the export of Indian coffee to Italy, Spain, other countries and Belgium was positive and increasing at the rate of 5.77 percent, 4.39 percent 3.68 percent and 3.39 percent respectively and found significant only in the case of Italy and other countries. Whereas, the growth in the export of Indian coffee in the case of USA $(-14.58 \%)$, Canada (-6.69\%), Russian Federation (-4.09\%) and Germany (-4.05\%) showed declining trend. The possible reasons for decline in the export of Indian coffee are competition from Columbia and Vietnam, the two major producers who have as well exploited the international markets having an export share of 20 percent and 8 percent respectively. Countries like

Table 2 Growth and instability in the export of Indian coffee
Germany, Italy, Belgium and USA who produce no coffee are also among major exporters. This speaks of the amount of value addition and branding that could make a country a major player in the world market. Though India has one of the best varieties of shade grown coffees, especially the Indian Robusta known for its strong blend, the major coffee markets of the world are not exploited by India due to lack of certification in India. ${ }^{1}$ Even poor value addition to Indian coffee even at a primary level is reflected out of the fact that nearly 70 percent of coffee exported by India is neither roasted nor decaffeinated and that has been worstly affected the Indian coffee trade (Ministry of agriculture, IIFT capacity building program).

\begin{tabular}{lllllll}
\hline Countries & CGR & Slope & $\mathbf{R}^{2}$ & ' $\mathbf{t}$ 'Value & $\mathbf{C V}$ & Instability index \\
\hline Belgium & 3.39 & 0.03 & 0.09 & 1.16 & 41.27 & 39.29 \\
Germany & -4.05 & $-0.04^{*}$ & 0.33 & 2.52 & 31.72 & 26.00 \\
Italy & 5.77 & $0.06^{* *}$ & 0.81 & 7.46 & 25.68 & 11.18 \\
Russian Federation & -4.09 & $-0.04^{* *}$ & 0.49 & 3.54 & 23.99 & 17.12 \\
Spain & 4.39 & 0.04 & 0.13 & 1.39 & 39.92 & 37.23 \\
Canada & -6.69 & $-0.07^{*}$ & 0.53 & 3.8 & 42.38 & 29.19 \\
USA & -14.58 & $-0.16^{* *}$ & 0.73 & 5.93 & 74.23 & 38.56 \\
Other Countries & 3.68 & $0.04^{* *}$ & 0.69 & 5.37 & 19.14 & 10.67 \\
Total export & 0.93 & 0.01 & 0.13 & 1.39 & - & - \\
\hline
\end{tabular}

\section{Note: ** Significant at $1 \%$ level}

*Significant at $5 \%$ level CV: Coefficient of variation.

To examine the stability of coffee export from India to different countries, the instability index in the export of coffee was estimated and results are presented in Table 2. Perusal of the table indicated that Belgium (39.29\%), USA (38.56\%), Spain (37.23\%), Canada $(29.19 \%)$ and Germany $(26.00 \%)$ are the most unstable importers of Indian coffee as they have registered increasing instability index over the years. Whereas, other countries $(10.67 \%)$, Italy $(11.18 \%)$ and Russian Federation (17.12\%) showed that they are the stable importer of the Indian coffee over the years. It could be said from the above discussion that with rise of Brazil and Vietnam in global coffee market India is losing out traditional coffee importers. Similar results were found in study conducted by Mamatha, ${ }^{2}$ where she estimated the growth rates of production and export of selected spices for the period from 1970-71 to 1991-92.

\section{Export competitiveness of Indian coffee in the world market}

The nominal protection coefficient (NPC) is used to find out the level of protection and level of government intervention in different commodities. It is interesting to visualize from the Table 3 that barring the year 1997, coffee is perfectly competitive with its NPC value being less than unity till 2000, indicating that coffee is worth to export. From 2000 onwards, the NPC value for coffee is more than unity, indicating that domestic price for coffee in India is more competitive than the international prices. As mentioned earlier even though there has been overall rise in domestic consumption of coffee but per capita consumption of coffee in India is still very low $(0.1 \mathrm{Kg}$ per annum, 137 th rank) compared to other countries. Historically, it has been proved that there are hardly any linkages between global and domestic coffee prices. Domestic prices have remained high despite a crash in global coffee prices. Cheap labour is one of the most critical cost factors in coffee production. Substantial increase in labour cost can erode competitiveness of Indian coffee in the international markets. Coffee is one of the few agricultural crops in India which is subject to taxes. Hike in taxes can substantially reduce margins to growers and serve as major disincentive. From the above discussion it is clear that Nominal Protection Coefficient (NPC) is not the sufficient parameter to decide the export competitiveness in case of coffee, because of high domestic price not fully supported by the demand as the consumption of coffee is mostly restricted to high income segments. Thus domestic market alone will not support Indian coffee production and hence export becomes necessary to sustain coffee industry. There are lessons to India from competitors in Central and Latin America who, in addition to leveraging on technology to increase the yield have made certification possible to a great extent without much cost with the existing local institutions and infrastructure. Finding a low cost model for individual farm certification calls for collaboration among a range of local and international actors which needs to be addressed through the right set of policies.

\section{Direction of trade of coffee export from India}

The transitional probability matrix, presented in Tables 4 depicts a broad idea of change in the direction of trade of Indian coffee over the study period. The four major countries which imported Indian coffee were: Belgium, Germany, Italy, Russian Federation and Spain. The export to remaining countries was pooled under the category of 'other countries'. It is evident from the table that, other countries are the most stable importer of the Indian coffee as the probability that 
other countries retained their original share from previous year was 83.00 percent. They lost their share of about 14.40 percent to Russian Federation, 1.86 percent to Italy and 0.74 percent to Spain even though the other countries gained considerable amount from Italy (30.20\%) and Russian Federation (8.62\%). Thus there is likely shift in shares of export of Indian coffee from Belgium, Italy and Russian Federation to other countries. Italy is another stable importer of Indian coffee as it retained 69.80 percent of its share from previous year by losing 30.20 percent to other countries, even though it gained considerable share from Spain (65.51\%), Belgium (14.39\%), Russian Federation $(12.56 \%)$ and other countries (1.86\%). While Spain is the least stable importer of Indian coffee as it retained only about 6.78 percent of its share from the previous year, by losing 65.51 percent share to Italy and 27.72 percent to Belgium but it gained 32.01 percent share from Belgium, followed by Germany $(21.51 \%)$ and other countries $(0.74 \%)$. Apart from Italy and other countries, Germany, Russian Federation and Belgium were also the stable importer of Indian coffee as they retained about 58.20 percent, 48.80 percent and 47.98 percent of their share from the previous year respectively and similar interpretation could be made for these countries. Hence, it would be necessary to give more stress on Spain. The plans for export should be oriented towards this country and also plans should be formulated for stabilizing the export to other countries. The reasons may be that there is a major shift in the consumption and thereby composition of demand for coffee in the developed (importing) countries which has had unfavorable effects on aggregate export earnings from coffee. While India also faces the threat from Columbia, Kenya or Ethiopia due to their better quality of coffees, there is also a threat from Brazil in terms of higher yield of coffee, especially for the robusta variety grown in the country. The country had adopted the strategy of large scale low cost coffee plantations to ensure large harvests and access to international markets. The development and implementation of new technologies have enabled a marked increase in the Brazilian coffee bean production. Coffee productivity in Brazil has steadily and comprehensively risen as a result of changes in technology. According to CECAFE statistics, bean productivity in Brazil increased by 76 percent from 1990 to 2000 .

Table 3 Trade competitiveness of Indian coffee

\begin{tabular}{ll}
\hline Year & NPC \\
\hline 1995 & 0.67 \\
1996 & 0.87 \\
1997 & 1.13 \\
1998 & 0.81 \\
1999 & 0.85 \\
2000 & 1.11 \\
2001 & 1.16 \\
2002 & 1.05 \\
2003 & 1.05 \\
2004 & 0.96 \\
2005 & 1.06 \\
2006 & 0.99 \\
2007 & 1.01 \\
2008 & 1.04 \\
2009 & 1.29 \\
2010 & 1.12 \\
\hline
\end{tabular}

Table 4 Transitional probability matrix of India coffee export (I995-96 to 2009-10)

\begin{tabular}{lllllll}
\hline Country & Belgium & Germany & Italy & Russian federation & Spain & Other countries \\
\hline Belgium & $\mathbf{0 . 4 7 9 8}$ & 0.0000 & 0.1439 & 0.0217 & 0.3201 & 0.0345 \\
Germany & 0.1525 & $\mathbf{0 . 5 8 2 4}$ & 0.0000 & 0.0500 & $0.215 \mathrm{I}$ & 0.0000 \\
Italy & 0.0000 & 0.0000 & $\mathbf{0 . 6 9 8 0}$ & 0.0000 & 0.0000 & 0.3020 \\
Russian Federation & 0.0188 & 0.2815 & 0.1256 & $\mathbf{0 . 4 8 8 0}$ & 0.0000 & 0.0862 \\
Spain & 0.2772 & 0.0000 & 0.6551 & 0.0000 & $\mathbf{0 . 0 6 7 8}$ & 0.0000 \\
Other countries & 0.0000 & 0.0000 & 0.0186 & 0.1440 & 0.0074 & $\mathbf{0 . 8 3 0 0}$
\end{tabular}

The projection of the Indian coffee export to different countries was computed using the transitional probability matrix and the results of actual and estimated exports of Indian coffee have been presented in Table 5. The market share projections of coffee exports to different countries have been computed up to 2015-16. It could be seen from the table that, the percentage share of actual and estimated export of coffee to Belgium had shown increasing trend between 1995-1996 and 2003-04. However, the projected value suggests that the percentage of quantity would slightly increase from 3.78 percent in 2010-11 to 5.41 percent by 2015-16. In the case of Germany, the percent share of actual export had shown decreasing trend from 1995-1996 to 2009-10 and the estimated value showed that the share of Germany was marginally increased from 12.25 percent to 12.83 percent between 2000-01 to 2002-03 and the projected market share is expected to increase during 2010-11 to 2015-16 from 7.92 percent to 9.69 percent. In the case of
Italy, the projected market share was expected to decrease marginally from 21.66 percent to 20.07 percent during 2010-11 to 2015-16 and similar trend was seen in the case of Russian Federation. The actual export share of coffee to Spain had decreased drastically from 5.07 percent in 1998-99 to 2.95 percent in 2009-10 however; the projected market share is also expected to increase marginally from 3.10 percent to 4.37 percent during 2010-11 to 2015-16. The actual export share to the countries pooled under 'others' showed a declining trend during $1995-96$ to $2009-10$ from 49.12 percent to 48.83 percent. The projected market share is also expected to decrease from 2010-11 to 2015-16. Keeping in view of the foregoing discussions, more stress has to be given on the countries such as Belgium, Germany, Italy and other countries category for maintaining present status of export and the government has to give more importance to the countries such as Spain and Russian Federation to maintain the market share in the 
future. The threat becomes intense to India when the competitors are increasing the share of sustainable coffee in the world markets, especially in the European and the Northern American Markets which is fastly moving towards certified coffee consumption. It is in this context, in India the problem of improvement of coffee safety in addition to coffee quality has to be considered. ${ }^{3}$ The Indian coffee
Board has endorsed the ICO quality plan as part of 7 steps to quality coffees. It has during 2004 brought out a guide to Indian coffee quality aimed at making quality specifications of Indian coffee grades even more transparent. Though there are some efforts by organizations like ITC and Coffee board towards attaining certification of coffee there is a need to scale up the operation in India (www.ico.org).

Table 5 Actual and projected exports of Indian coffee to major importing countries

\begin{tabular}{|c|c|c|c|c|c|c|c|c|c|c|c|c|}
\hline \multirow[t]{2}{*}{ Year } & \multicolumn{2}{|c|}{ Belgium } & \multicolumn{2}{|l|}{ Germany } & \multicolumn{2}{|l|}{ Italy } & \multicolumn{2}{|c|}{ Russian Federation } & \multicolumn{2}{|l|}{ Spain } & \multicolumn{2}{|l|}{ Others } \\
\hline & A & $\mathbf{P}$ & A & $\mathbf{P}$ & A & $\mathbf{P}$ & $\mathbf{A}$ & $\mathbf{P}$ & A & $\mathbf{P}$ & A & $\mathbf{P}$ \\
\hline \multirow[t]{2}{*}{2000} & 17993 & 17855 & 30256 & 30010 & 40004 & 45825 & 44435 & 33912 & 14498 & 14379 & 99722 & 102960 \\
\hline & (7.29) & (7.29) & $(12.25)$ & $(12.25)$ & $(16.20)$ & $(18.7 I)$ & $(18.00)$ & (13.85) & $(5.87)$ & $(5.87)$ & (40.39) & (42.03) \\
\hline \multirow[t]{2}{*}{2001} & $|566|$ & 18098 & 27589 & 30129 & 41842 & 47446 & 40301 & 37944 & 12209 & 13992 & 75984 & 99299 \\
\hline & (7.33) & $(7.33)$ & $(12.92)$ & $(12.20)$ & (19.59) & $(19.22)$ & $(18.87)$ & (I5.37) & $(5.72)$ & $(5.67)$ & (35.58) & $(40.22)$ \\
\hline \multirow[t]{2}{*}{2002} & 17430 & 15860 & 23344 & 27412 & 45594 & 45933 & 36578 & 32325 & 11142 & 12340 & 73245 & 79716 \\
\hline & $(8.4 I)$ & (7.43) & $(11.26)$ & $(I 2.83)$ & $(21.99)$ & $(2 I .5 I)$ & (17.64) & $(15.13)$ & $(5.37)$ & $(5.78)$ & (35.33) & (37.32) \\
\hline \multirow[t]{2}{*}{2003} & 18777 & 15696 & 25680 & 23892 & 52197 & 47589 & 33592 & 29940 & 13898 & 11900 & 88540 & 78316 \\
\hline & $(8.07)$ & $(7.57)$ & (II.04) & (II.52) & $(22.43)$ & (22.95) & (14.44) & (14.44) & $(5.97)$ & $(5.74)$ & (38.05) & (37.77) \\
\hline \multirow[t]{2}{*}{2004} & 9204 & 17406 & 16518 & 24412 & 49232 & 54107 & 34459 & 30831 & 11499 & 13135 & 90853 & 92794 \\
\hline & $(4.35)$ & (7.48) & $(7.80)$ & $(10.49)$ & $(23.25)$ & $(23.25)$ & (16.27) & $(13.25)$ & $(5.43)$ & $(5.64)$ & $(42.90)$ & (39.88) \\
\hline \multirow[t]{2}{*}{2005} & 11190 & 10768 & 16742 & 19320 & 53413 & 49240 & 29432 & 30921 & 10292 & 7954 & 80486 & 93562 \\
\hline & $(5.55)$ & $(5.08)$ & $(8.31)$ & $(9.12)$ & $(26.50)$ & (23.25) & $(14.60)$ & $(14.60)$ & $(5 . I I)$ & (3.76) & (39.93) & (44.18) \\
\hline \multirow[t]{2}{*}{2006} & I3989 & 11326 & 21835 & 18035 & 62807 & 50829 & 27447 & 27029 & II09| & 8479 & ||$|86|$ & 85856 \\
\hline & $(5.62)$ & $(5.62)$ & $(8.77)$ & $(8.95)$ & $(25.22)$ & $(25.22)$ & $(11.02)$ & $(|3.4|)$ & $(4.45)$ & $(4.21)$ & $(44.92)$ & $(42.60)$ \\
\hline \multirow[t]{2}{*}{2007} & 10615 & 13630 & 14236 & 20443 & 53804 & 58647 & 25183 & 30893 & 8802 & 10758 & 106356 & 114659 \\
\hline & $(4.85)$ & (5.47) & $(6.50)$ & $(8.21)$ & $(24.57)$ & $(23.55)$ & (II.50) & $(\mid 2.4 I)$ & $(4.02)$ & $(4.32)$ & $(48.57)$ & $(46.04)$ \\
\hline \multirow[t]{2}{*}{2008} & 9673 & 10175 & $147 \mid 5$ & 15380 & 51207 & 49992 & 16143 & 28542 & 8556 & 7847 & 96880 & 107060 \\
\hline & (4.91) & $(4.65)$ & (7.46) & (7.02) & $(25.97)$ & $(22.83)$ & $(8.19)$ & $(13.03)$ & $(4.34)$ & (3.58) & $(49.13)$ & (48.89) \\
\hline \multirow[t]{2}{*}{2009} & 7168 & 9559 & 13469 & 13114 & 48302 & |4657| & 29652 & 22770 & 6038 & 7562 & 99842 & 97599 \\
\hline & $(3.5 I)$ & $(4.85)$ & (6.59) & $(6.65)$ & $(23.62)$ & $(23.62)$ & $(14.50)$ & (II.55) & $(2.95)$ & (3.84) & $(48.83)$ & $(49.50)$ \\
\hline \multirow[t]{2}{*}{2010} & - & 7722 & - & 16191 & - & 44285 & - & 29672 & - & 6343 & - & 100257 \\
\hline & & (3.78) & & $(7.92)$ & & $(21.66)$ & & $(|4.5|)$ & & $(3.10)$ & & (49.03) \\
\hline \multirow[t]{2}{*}{2011} & - & 8488 & - & 17782 & - & $4|77|$ & - & 29890 & - & 7130 & - & 99410 \\
\hline & & $(4.15)$ & & $(8.70)$ & & $(20.43)$ & & $(14.62)$ & & (3.49) & & (48.62) \\
\hline \multirow[t]{2}{*}{2012} & - & 9321 & - & 18770 & - & 40653 & - & 2997| & - & 7764 & - & 97992 \\
\hline & & $(4.56)$ & & $(9.18)$ & & $(19.88)$ & & $(14.66)$ & & $(3.80)$ & & (47.92) \\
\hline \multirow[t]{2}{*}{2013} & - & 10048 & - & 19368 & - & 40392 & - & 29873 & - & 8276 & - & 96514 \\
\hline & & $(4.91)$ & & (9.47) & & $(19.75)$ & & $(\mid 4.6 I)$ & & $(4.05)$ & & $(47.20)$ \\
\hline \multirow[t]{2}{*}{2014} & - & 10628 & - & 19689 & - & 40610 & - & 29659 & - & 8661 & - & 95225 \\
\hline & & $(5.20)$ & & $(9.63)$ & & $(19.86)$ & & $(\mid 4.5 I)$ & & $(4.24)$ & & (46.57) \\
\hline \multirow[t]{2}{*}{2015} & - & 11058 & - & 19815 & - & 41046 & - & 29397 & - & 8932 & - & 94222 \\
\hline & & $(5.4 I)$ & & (9.69) & & $(20.07)$ & & (14.38) & & $(4.37)$ & & $(46.08)$ \\
\hline
\end{tabular}

Note: A-Actual exports in tonnes. P-Predicted exports in tonnes. Figures in the parentheses indicate export share in percent. 


\section{Conclusion}

Looking into the export performance of coffee there was slight decline in the India's share in the global coffee trade. This may be attributed to favorable domestic prices, increase in internal consumption. However, Indian coffee industry cannot depend solely on domestic market due to its lower per capita consumption and surplus production. Hence, there is a need to make the Indian coffee competitive in the international market, as it is facing stiff competition from Brazil and Vietnam in exporting to major coffee consuming countries like USA and Canada. In this direction efforts should be made to reduce cost of production of coffee so as make it more competitive on the global platform. It is also worth considering the possibility of re-export by importing low priced coffee from Vietnam and Indonesia. The value addition in supply chain is important for the sustainability of the coffee sector in India. The coffee products of India are constrained by logistic problems there by experiencing higher transaction cost affecting the export competitiveness. Therefore, efforts should be made to improve the logistic facilities and creating favorable environment for both private as well as public investment for value addition in coffee supply chain. So that Indian coffee sector can become globally competitive. The emphasis in pattern of coffee growing in India has to shift from just economic viability in terms of profits and returns to environmental aspects of sustainability. There is a move towards growing more of differentiated subset of sustainable coffees like organic, fair trade, eco friendly value based products on account of distinct origin specialized processes or exceptional characteristics like superior taste or zero defects.

\section{Acknowledgements}

None.

\section{Conflict of interest}

The author declares no conflict of interest.

\section{References}

1. Deepika MG. Export performance and factors affecting competiveness of plantation commodities in India. NRPPD Discussion Paper, Center for Development Studies, India; 2015. p. 1-45.

2. Mamatha BG. Export trade of selected spices in India-An economic analysis. Master of Science Thesis, University of Agricultural Sciences, Bangalore, India; 1995.

3. Ramesh Bhat V. Review of coffee quality/safety management and control in India. Centre for Science, Society and Culture, FAO, USA; 2005. p. $1-40$. 